Brit. Heart F., 1967, 29, 317.

\title{
Lung Function in Patients with Left-to-right Shunts
}

\author{
HYWEL DAVIES AND NIKOS GAZETOPOULOS
}

\author{
From the Cardiac Department, Guy's Hospital, London S.E.1
}

Increased work of breathing and excessive ventilatory response to exercise are intimately concerned with dyspncea on effort. In patients with left-toright shunts we have noted that dyspnœea occurred on exercise without greatly excessive ventilatory response (Gazetopoulos and Davies, 1966), and it was suggested that abnormal lung mechanics leading to increased work of breathing was an important factor in the genesis of their disability. Little information is available about this aspect of the natural history of such patients, but it has been suggested (Davies, Williams, and Wood, 1962) that hyperkinetic pulmonary hypertension may be associated with an alteration in the mechanical properties of the lungs. This paper is concerned with studies of lung function in patients with left-to-right shunts, with particular reference to the compliance of the lungs.

\section{SUBJECtS AND METhODS}

Lung function studies were performed in 97 patients with left-to-right shunts. They were divided into the following five groups. Group I: atrial septal defect with normal pulmonary arterial pressure (26 cases); Group II: atrial septal defect with large left-to-right shunts and pulmonary hypertension (17 cases); Group III: Ventricular septal defect with normal pulmonary arterial pressure (19 cases); Group IV : ventricular septal defect with large left-to-right shunts and pulmonary hypertension (20 cases); and Group $V$ : Eisenmenger syndrome (15 cases).

The first four groups thus consisted of those patients who had a dominant left-to-right shunt, usually with a pulmonary:systemic flow ratio greater than $2: 1$ and with corresponding clinical signs. The fifth group consisted of patients with severe increase in pulmonary vascular resistance and clinical and hæmodynamic evidence of the Eisenmenger syndrome, as defined by Wood (1958). A systolic pulmonary arterial pressure above $40 \mathrm{~mm}$. $\mathrm{Hg}$ has been used to denote the presence of pulmonary hypertension.

Received December 23, 1965.

$\mathbf{Y}$
Ventilatory function was assessed with the use of a dry bell spirometer (Godart). Functional residual capacity (FRC) was measured by the closed-circuit helium dilution method of McMichael (1939). Predicted values for FRC were calculated from the patient's height and weight using the regression equations of Needham, Rogan, and McDonald (1954) in adults, and Helliesen et al. (1958) below the age of 17. Vital capacity was predicted from the tables of Myers (1925). Peak flow was assessed by means of a peak flow-meter. Diffusion capacity was estimated by measurement of the carbon monoxide uptake and fractional removal, at rest, as described by Bates (1952).

Measurement of lung compliance was achieved by passing a thin latex balloon $10 \mathrm{~cm}$. long into the retrocardiac segment of the csophagus via the nostril. The balloon was connected through a polythene tube of 1.5 $\mathrm{mm}$. internal diameter to an inductance manometer, the other side of this being connected to the mouthpiece. The differential pressure between osophagus and mouth (transpulmonary pressure) was thereby recorded after amplification either with a cathode-ray oscilloscope and camera or an ultraviolet recorder. The tidal volume during quiet breathing was recorded by means of a spirometer with linear-wound potentiometer or with a Fleisch pneumotachograph whose output was electrically integrated and amplified. The pressure swing was measured between the points of no-flow in the tidal volume range. All compliance measurements were made in the sitting position.

\section{RESULTS}

The findings in the different groups studied are shown in Table I.

Forced vital capacity (FVC) was measured in 85 patients. Many showed impairment, but the mean values were not greatly removed from normal and there was no significant difference between the groups (Fig. 1).

Forced expiratory ratio $\left(\mathrm{FEV}_{1 \cdot 0} / \mathrm{FVC}\right)$ was me2sured in 66 patients and the mean values were found to be normal in all groups, as was the peak expiratory 
TABLE

HEMODYNAMIC AND LUNG FUNCTION DATA IN FIVE

\begin{tabular}{|c|c|c|c|c|c|c|c|}
\hline \multirow[t]{2}{*}{ Group* } & \multirow[t]{2}{*}{$\begin{array}{l}\text { No. of } \\
\text { patients }\end{array}$} & \multicolumn{2}{|c|}{ Age (yr.) } & \multicolumn{2}{|c|}{$\begin{array}{c}\text { Pulmonary arterial pressure } \\
(\mathrm{mm} . \mathbf{H g})\end{array}$} & \multicolumn{2}{|c|}{ Flow index $\left(1 . / \mathrm{min} . / \mathrm{m} .{ }^{2}\right)$} \\
\hline & & & & Systolic & Diastolic & Pulmonary & Systolic \\
\hline $\mathbf{I}$ & 26 & $\begin{array}{l}\text { Mean } \\
\text { SD } \\
\text { Range }\end{array}$ & ${ }_{9-42}^{22}$ & $\begin{array}{l}22 \\
8 \\
18-36\end{array}$ & $\begin{array}{l}8(24) \\
4 \\
5-15\end{array}$ & $\begin{array}{c}11 \cdot 5(24) \\
5 \cdot 1 \\
5 \cdot 4-23 \cdot 3\end{array}$ & $\begin{array}{l}3 \cdot 4(24) \\
0 \cdot 8 \\
2 \cdot 4-5 \cdot 6\end{array}$ \\
\hline II & 17 & $\begin{array}{l}\text { Mean } \\
\text { SD } \\
\text { Range }\end{array}$ & $\begin{array}{l}49 \\
11 \\
24-59\end{array}$ & $\begin{array}{l}59 \\
15 \\
40-85\end{array}$ & $\begin{array}{l}25(17) \\
9 \\
15-40\end{array}$ & $\begin{array}{l}8 \cdot 6(17) \\
5 \cdot 9 \\
9 \cdot 4-22 \cdot 2\end{array}$ & $\begin{array}{l}2 \cdot 4(17) \\
0.5 \\
1 \cdot 5-4.5\end{array}$ \\
\hline III & 19 & $\begin{array}{l}\text { Mean } \\
\text { SD } \\
\text { Range }\end{array}$ & $\begin{array}{l}19 \\
13 \\
6-56\end{array}$ & $\begin{array}{l}29 \\
14 \\
15-38\end{array}$ & $\begin{array}{l}11(19) \\
5-20\end{array}$ & $\begin{array}{l}7 \cdot 8(19) \\
3 \cdot 0 \\
3 \cdot 0-13 \cdot 6\end{array}$ & $\begin{array}{l}3 \cdot 7(19) \\
1 \cdot 1 \\
2 \cdot 1-5 \cdot 5\end{array}$ \\
\hline IV & 20 & $\begin{array}{l}\text { Mean } \\
\text { SD } \\
\text { Range }\end{array}$ & $\begin{array}{l}21 \\
15 \\
6-62\end{array}$ & $\begin{array}{l}80 \\
25 \\
50-130\end{array}$ & $\begin{array}{c}39(20) \\
18 \\
5-75\end{array}$ & $\begin{array}{c}10 \cdot 8(20) \\
6 \cdot 8 \\
3 \cdot 8-30 \cdot 0\end{array}$ & $\begin{array}{l}3 \cdot 6(20) \\
1 \cdot 2 \\
2 \cdot 1-6 \cdot 2\end{array}$ \\
\hline $\mathbf{v}$ & 15 & $\begin{array}{l}\text { Mean } \\
\text { SD } \\
\text { Range }\end{array}$ & $\begin{array}{l}27 \\
10 \\
9-55\end{array}$ & $\begin{array}{l}114 \\
24 \\
75-150\end{array}$ & $\begin{array}{l}58(12) \\
17 \\
40-80\end{array}$ & $\begin{array}{l}3 \cdot 8(12) \\
1 \cdot 9 \\
1 \cdot 1-6 \cdot 6\end{array}$ & $\begin{array}{l}3 \cdot 0(12) \\
0 \cdot 8 \\
2 \cdot 1-4 \cdot 5\end{array}$ \\
\hline
\end{tabular}

$\star$ For definition, see text.

FEV $1.0=$ forced expiratory volume in 1 sec.; $F V C=$ forced vital capacity; $F R C=$ functional residual capacity; $C=$ compliance.

Figures in parentheses refer to number of cases.

flow (Table I). Sporadically low values were seen for these parameters, but there was no evidence of increased airway resistance in these patients (Fig. 2 and 3).

The carbon monoxide uptake, measured in 38 patients, was normal or high-normal in all groups, without any significant difference between them (Fig. 4).

Functional residual capacity (FRC) was measured in 38 patients. Fig. 5 shows the relation between measured and predicted values. It is seen that the four cases of atrial septal defect with pulmonary hypertension (Group II) show an increase in FRC relative to the predicted value: otherwise no consistent pattern is seen. (The low mean FRC in Group IV (Table I) is due to the preponderance of young patients amongst the 7 in whom this was measured.)

Lung compliance was measured in 78 patients. Patients in Group III consisted in the main of young subjects with normal pulmonary arterial

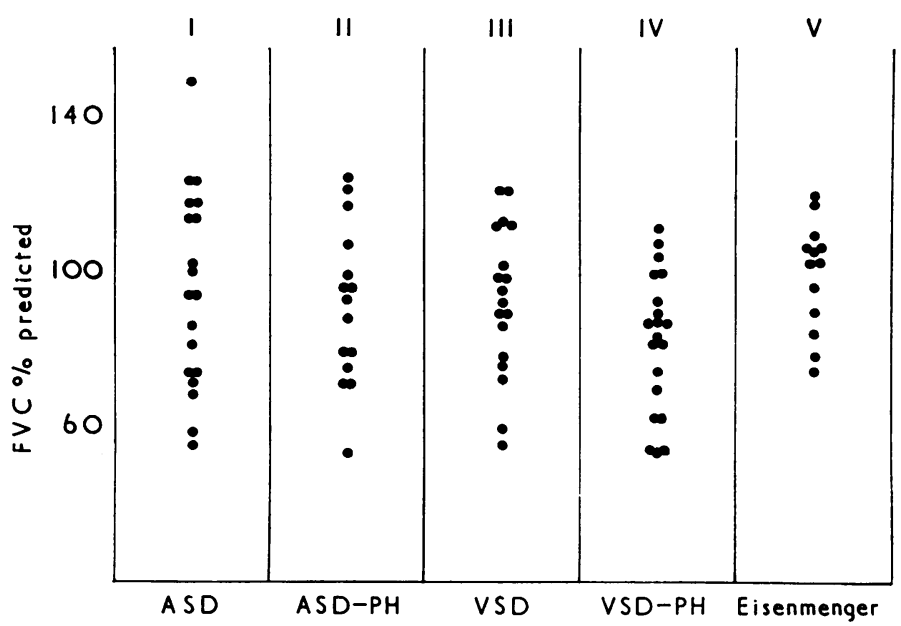

Fig. 1.-Forced vital capacity expressed as percentage of predicted normal in five groups of patients with left-to-right shunts. $A S D=$ atrial septal defect; $V S D=$ ventricular septal defect. $P H=$ pulmonary arterial hypertension. 
I GROUPS OF PATIENTS WITH LEFT-TO-RIGHT SHUNTS

\begin{tabular}{|c|c|c|c|c|c|c|}
\hline $\begin{array}{c}\text { FVC \% of } \\
\text { predicted normal }\end{array}$ & $\frac{\text { FEV }_{1 \cdot 0}}{\text { FVC }_{\%}}$ & $\begin{array}{c}\text { Peak } \\
\text { expiratory } \\
\text { flow } \\
(1 . / \mathrm{min} .)\end{array}$ & $\mathrm{CO}_{2} \underset{\%}{\text { uptake }}$ & $\begin{array}{l}\text { FRC } \\
\text { (1.) }\end{array}$ & $\begin{array}{c}\text { Compliance } \\
\left(1 . / \mathrm{cm} . \mathrm{H}_{2} \mathrm{O}\right)\end{array}$ & $\begin{array}{c}\text { Specific } \\
\text { compliance } \\
\frac{\mathrm{C}}{\text { FRC }}\end{array}$ \\
\hline $\begin{array}{l}93(19) \\
25 \\
56-150\end{array}$ & $\begin{array}{l}77(16) \\
17-96 \\
39-96\end{array}$ & $\begin{array}{l}420(14) \\
106 \\
250-620\end{array}$ & $\begin{array}{c}63(7) \\
330-70\end{array}$ & $\begin{array}{l}2.7(11) \\
1.0 \\
1 \cdot 3-5.9\end{array}$ & $\begin{array}{l}0.13(19) \\
0.07 \\
0.05-0.35\end{array}$ & $\begin{array}{l}0.05(11) \\
0.02 \\
0.03-0.08\end{array}$ \\
\hline $\begin{array}{l}92(15) \\
20 \\
54-125\end{array}$ & $\begin{array}{l}75(14) \\
10 \\
60-85\end{array}$ & $\begin{array}{l}360(13) \\
124 \\
180-580\end{array}$ & $\begin{array}{l}60(10) \\
10 \\
45-77\end{array}$ & $\begin{array}{l}3 \cdot 7(4) \\
1 \cdot 4 \\
2 \cdot 2-5 \cdot 1\end{array}$ & $\begin{array}{l}0.14(11) \\
0.06 \\
0.04-0.21\end{array}$ & $\begin{array}{l}0.03 \text { (4) } \\
0.01 \\
0.02-0.04\end{array}$ \\
\hline $\begin{array}{l}93(18) \\
21 \\
56-130\end{array}$ & $\begin{array}{c}85(7) \\
9 \\
75-100\end{array}$ & $\begin{array}{l}430(7) \\
137 \\
280-650\end{array}$ & $\begin{array}{l}60(5) \\
11 \\
52-81\end{array}$ & $\begin{array}{l}2.3(12) \\
0.8 \\
0.9-4.0\end{array}$ & $\begin{array}{l}0.16(18) \\
0.07 \\
0.05-0.34\end{array}$ & $\begin{array}{l}0.06 \text { (12) } \\
0.02 \\
0.04-0.09\end{array}$ \\
\hline $\begin{array}{l}82(20) \\
17 \\
55-112\end{array}$ & $\begin{array}{l}81(15) \\
10 \\
63-95\end{array}$ & $\begin{array}{l}350(12) \\
114 \\
140-490\end{array}$ & $\begin{array}{c}59(10) \\
8 \\
43-69\end{array}$ & $\begin{array}{l}1.6(7) \\
0.9 \\
0.9-3.6\end{array}$ & $\begin{array}{l}0.08 \text { (18) } \\
0.04 \\
0.02-0.19\end{array}$ & $\begin{array}{l}0.03(7) \\
0.01 \\
0.02-0.04\end{array}$ \\
\hline $\begin{array}{c}102(13) \\
14 \\
75-120\end{array}$ & $\begin{array}{l}80(14) \\
10 \\
61-93\end{array}$ & $\begin{array}{l}460(10) \\
136 \\
250-630\end{array}$ & $\begin{array}{c}59(6) \\
4 \\
55-63\end{array}$ & $\begin{array}{l}3 \cdot 1(4) \\
0 \cdot 7 \\
2 \cdot 2-3 \cdot 9\end{array}$ & $\begin{array}{l}0.15(11) \\
0.06 \\
0.05-0.21\end{array}$ & $\begin{array}{l}0.05 \text { (4) } \\
0.01 \\
0.04-0.07\end{array}$ \\
\hline
\end{tabular}

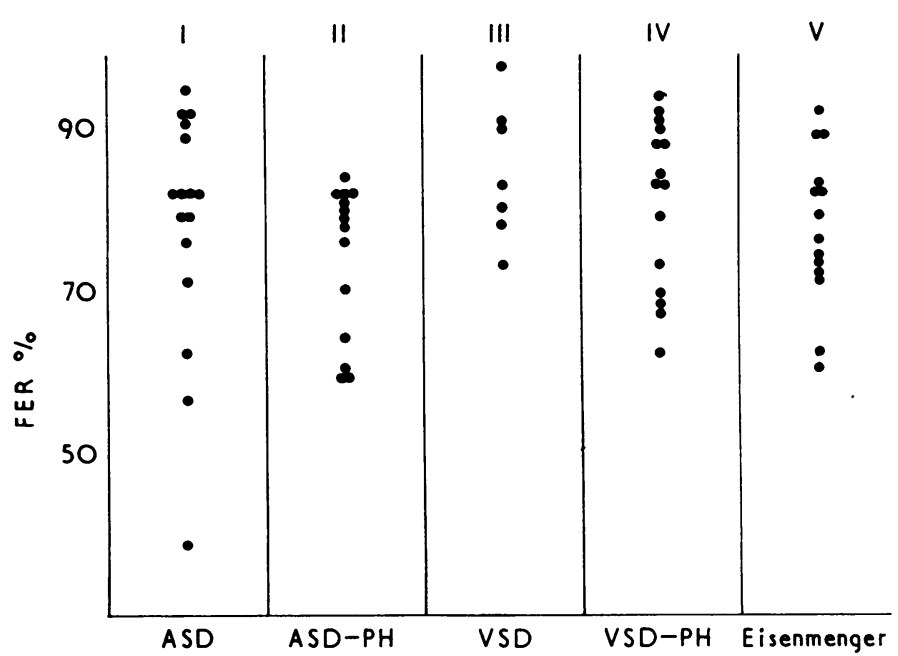

Fig. 2.-Forced expiratory resistance in five groups of left-to-right shunts. Abbreviations as in Fig. 1.

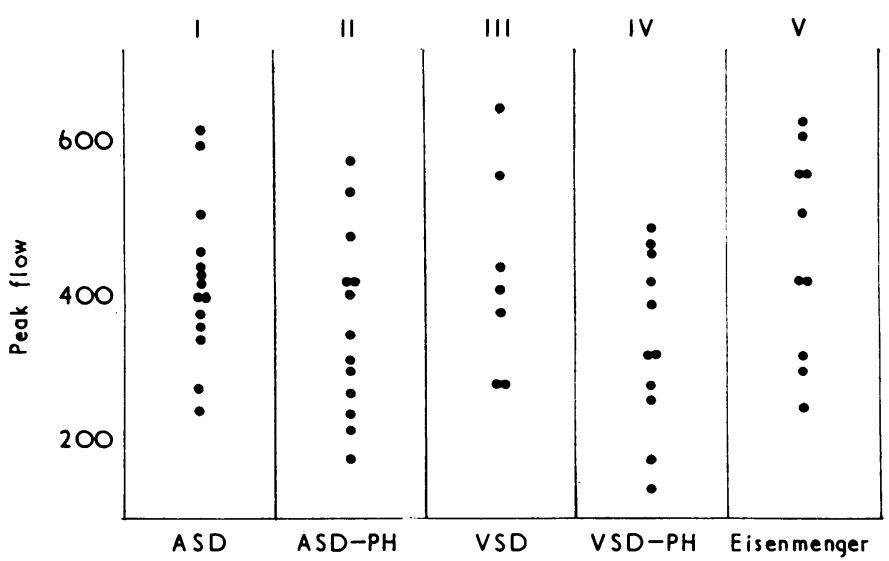

FIG. 3.-Peak expiratory flow in five groups of left-to-right shunts. Abbreviations as in Fig. 1. 


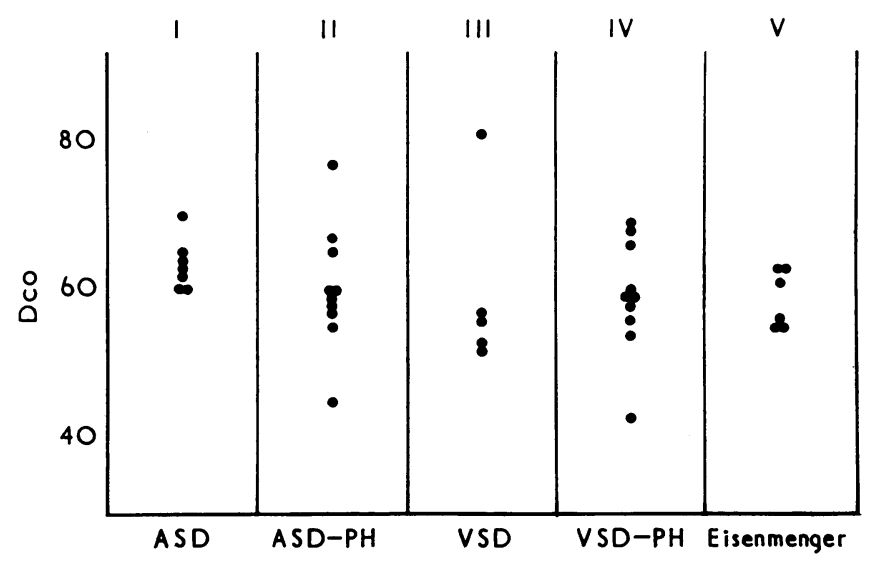

Fig. 4.-Carbon monoxide uptake (Dco) expressed as percentage in five groups of left-to-right shunts. Abbreviations as in Fig. 1.

pressures and small left-to-right shunts, and this group has therefore been taken as the basis of reference with which to compare the other groups. Patients with atrial septal defect and normal pulmonary arterial pressure (Group I) showed a slight reduction in compliance, but the difference from Group III is not significant $(p>0.05)$. Patients

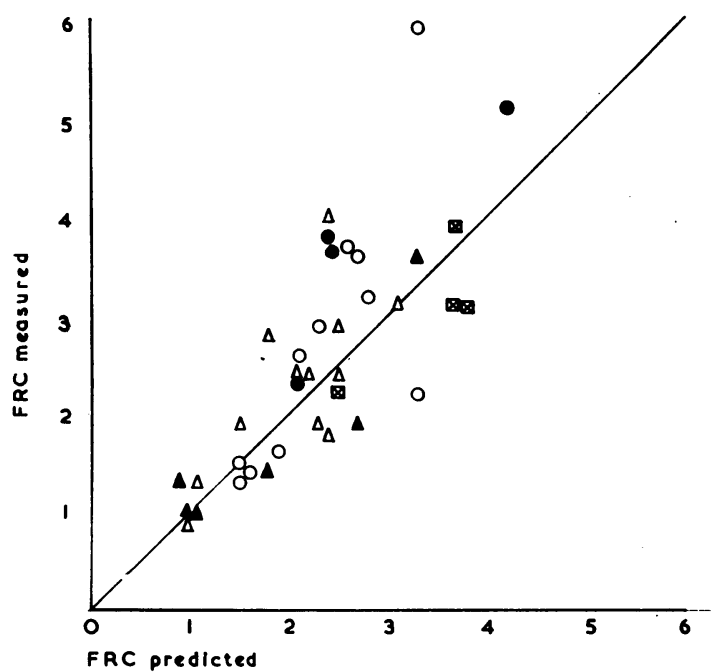

FIG. 5.-Functional residual capacity in litres, the measured value expressed as ordinate and the predicted value (see text) as abscissa, in 38 patients with left-to-right shunts.

$\triangle$ Group I. ASD with normal PA pressure.

$\Delta$ Group II. ASD with pulmonary hypertension.

O Group III. VSD with normal PA pressure.

- Group IV. VSD with pulmonary hypertension.

$\otimes$ Group V. Eisenmenger syndrome. Groups as defined in text. with atrial septal defect and pulmonary hypertension (Group II) have a measured compliance that does not differ significantly from normal, while those with ventricular septal defect and pulmonary hypertension (Group IV) show a reduced compliance, differing significantly from that of Group III $(p<0.001)$. Patients with the Eisenmenger syndrome (Group V) have normal compliance (Table I).

Since compliance is a function of lung size, these findings have limited meaning unless lung size is taken into account. In Fig. 6 the compliance is plotted against the measured FRC and in Fig. 7 the "specific compliance" (C/FRC) is shown in the five groups. The findings are similar in all groups except Group II, where despite the few measurements of FRC, the increased values for this parameter reduce the specific compliance to values that are significantly different from those of Group III $(0.05>p>0.01)$.

Thus, in both groups in which pulmonary hypertension is associated with increased pulmonary blood flow, a significant reduction in the specific lung compliance is observed.

Fig. 8 relates the specific compliance to the pulmonary flow index, patients with the Eisenmenger syndrome being designated by solid symbols. The relation between them is not statistically significant $(p>0 \cdot 1)$.

Fig. 9 shows the specific compliance in relation to the mean pulmonary arterial pressure, the patients in Group V (Eisenmenger) being designated by solid symbols. Excluding the latter, a significant relation exists between the two variables ( $r=$ $-0.378,0.05>p>0.01)$. In other words, when the pulmonary flow is greatly increased, the specific lung compliance tends to diminish with increasing pulmonary arterial pressure. 


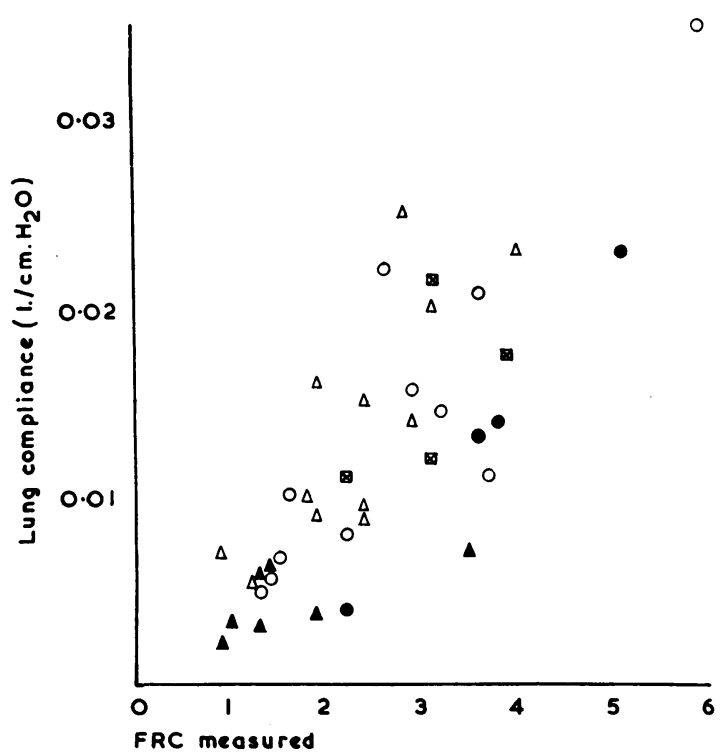

FIG. 6.- - Lung compliance in relation to measured functional residual capacity (FRC) in 38 patients with left-to-right shunts. Symbols as in Fig. 5.

In order to examine larger groups of patients the specific compliance based on predicted FRC was plotted against the pulmonary arterial pressure (Fig. 10). The relation is not significant $(r=$ $-0 \cdot 113, p>0 \cdot 1)$, and in the Eisenmenger group (solid symbols) the relation is if anything reversed. The relation is also not significant when the specific

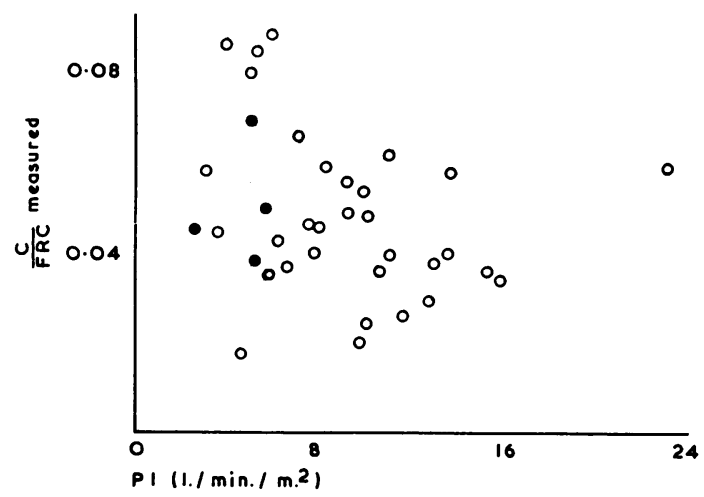

FIG. 8.-Specific compliance $(\mathrm{C} / \mathrm{FRC})$ in relation to the pulmonary flow index (PI). No significant relationship exists. Solid symbols denote Eisenmenger syndrome.

compliance is plotted against the pulmonary vascular resistance.

Since the impression has been gained that the combination of high pressure and high flow in the pulmonary arterial circuit was associated with disturbance of pulmonary mechanics (Davies et al., 1962), the product of these parameters has also been plotted against the specific compliance. Using the predicted FRC the relation is significant $(r=-0.318,0.01>p>0.001)$. When the measured FRC is used the relation is highly significant $(r=-0.566, p<0.001)$ (Fig. 11). The patients with the Eisenmenger syndrome then fall into line with the others, since their low pulmonary blood

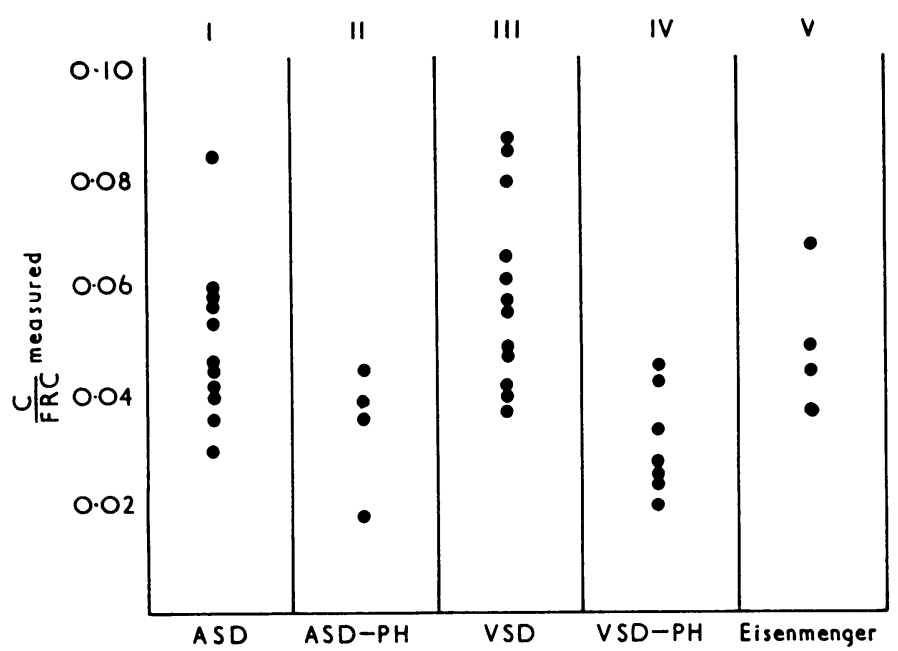

FIG. 7.-The specific compliance (C/FRC) in the five groups with left-to-right shunts (38 cases). Pulmonary hypertension with increased pulmonary flow is associated with impaired compliance (Groups II and IV), but hypertension or increased flow separately does not lower compliance (Groups I, III, and V). Abbreviations as in Fig. 1. 


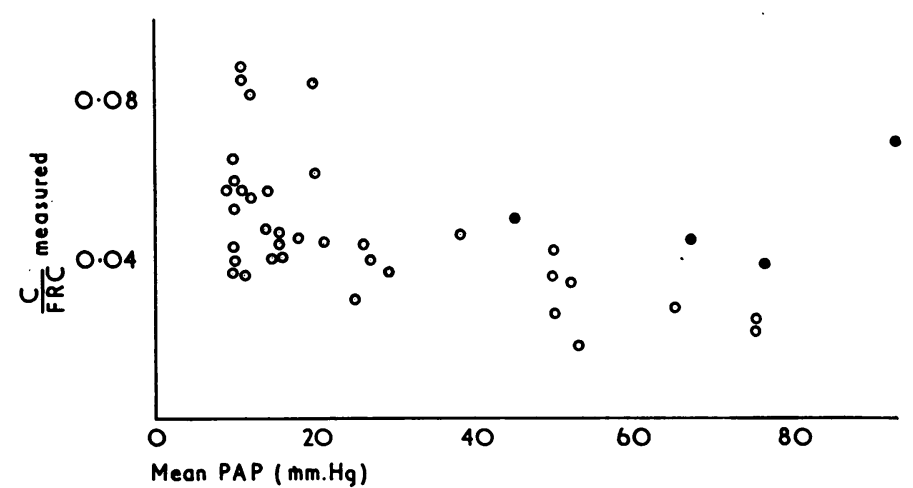

FIG. 9.-Specific compliance (C/FRC) based on measured FRC in relation to mean pulmonary arterial pressure (PAP). Cases in the Eisenmenger group are shown with solid symbols. Excluding these, the relation is significant $(\mathrm{r}=-0.378,0.05>\mathrm{p}>0.01)$.

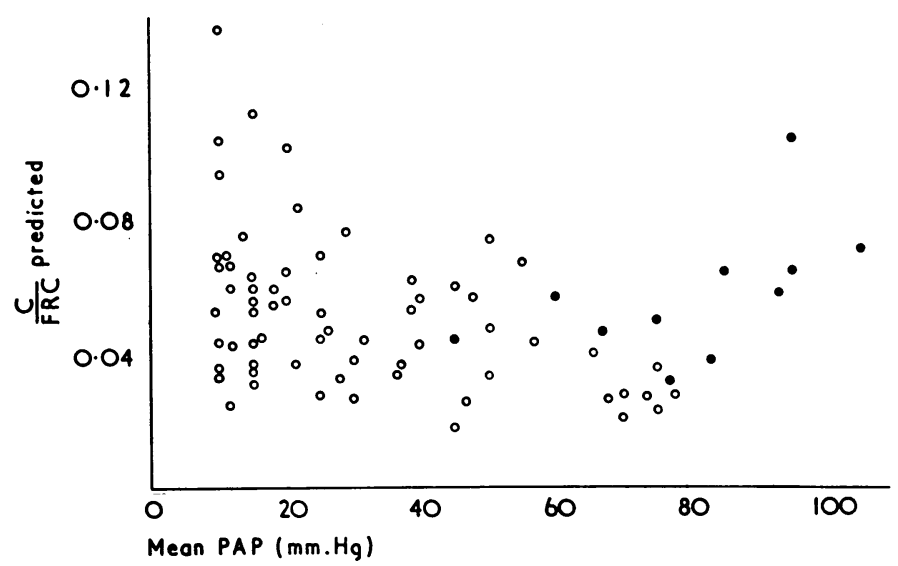

FIG. 10.-Specific compliance (C/FRC) based on predicted FRC in relation to mean pulmonary arterial pressure (PAP). Excluding the Eisenmenger patients (solid symbols), the relation is not significant $(r=-0 \cdot 113$, $\mathrm{p}>0 \cdot 1)$.

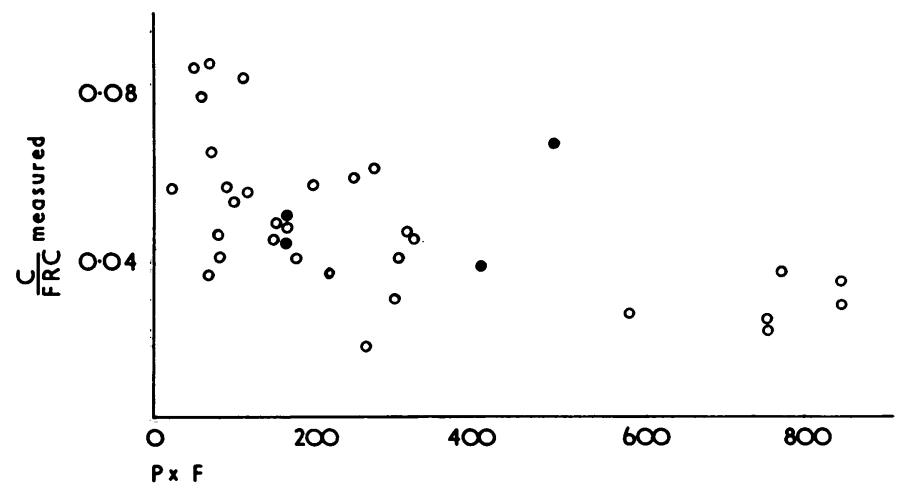

FIG. 11.-Specific compliance (C/FRC) in relation to the product of mean pulmonary arterial pressure (PAP) and pulmonary flow index (PI) (the "hyperkinetic index"-see text). The relation is highly significant $(r=-0.566, p<0.001)$. Solid symbols denote Eisenmenger syndrome. 
TABLE II

LUNG FUNCTION IN 7 PATIENTS BEFORE AND AFTER CLOSURE OF AN ATRIAL SEPTAL DEFECT

\begin{tabular}{|c|c|c|c|c|c|c|c|c|}
\hline Case No. & $\begin{array}{c}\text { Age at } \\
\text { operation } \\
\text { (yr.) }\end{array}$ & $\begin{array}{l}\text { Time of } \\
\text { study }\end{array}$ & $\begin{array}{c}\text { Disability } \\
\text { grade }\end{array}$ & $\begin{array}{c}\text { Pulmonary } \\
\text { arterial } \\
\text { pressure } \\
(\mathrm{mm} . \mathrm{Hg})\end{array}$ & $\begin{array}{c}\text { FVC } \\
\% \text { of } \\
\text { predicted } \\
\text { normal }\end{array}$ & $\frac{\text { FEV }_{1 \cdot 0}}{\text { FVC }}$ & $\begin{array}{c}\text { Peak } \\
\text { expiratory } \\
\text { flow } \\
\text { (1./min.) }\end{array}$ & $\begin{array}{c}\text { Compliance } \\
\left(1 . / \mathrm{cm} . \mathrm{H}_{2} \mathrm{O}\right)\end{array}$ \\
\hline 1 & 58 & $\begin{array}{l}\text { Before operation } \\
8 \mathrm{mth} \text {. after }\end{array}$ & $\begin{array}{l}\text { II } \\
\text { O }\end{array}$ & $\underline{55 / 25}$ & $\begin{array}{r}100 \\
88\end{array}$ & $\begin{array}{l}62 \\
45\end{array}$ & $\begin{array}{l}180 \\
120\end{array}$ & $\begin{array}{l}0 \cdot 16 \\
0 \cdot 30\end{array}$ \\
\hline 2 & 49 & $\begin{array}{l}\text { Before operation } \\
1 \mathrm{mth} \text {. after } \\
5 \mathrm{mth} \text {. after } \\
12 \mathrm{mth} \text {. after } \\
20 \mathrm{mth} \text {. after }\end{array}$ & $\begin{array}{l}\text { II-III } \\
\frac{\mathrm{O}}{\mathrm{O}} \\
\mathrm{O}\end{array}$ & $\begin{array}{l}\frac{80 / 40}{\bar{E}} \\
30 / 17\end{array}$ & $\begin{array}{r}97 \\
80 \\
118 \\
111 \\
100\end{array}$ & $\begin{array}{l}79 \\
87 \\
79 \\
83 \\
82\end{array}$ & $\begin{array}{l}425 \\
420 \\
420 \\
420 \\
390\end{array}$ & $\begin{array}{l}0.11 \\
0.11 \\
0.25 \\
0.18 \\
0.20\end{array}$ \\
\hline 3 & 32 & $\begin{array}{l}\text { Before operation } \\
0.5 \mathrm{mth} \text {. after } \\
13 \mathrm{mth} \text {. after }\end{array}$ & $\frac{\text { II }}{\text { I }}$ & ב & $\begin{array}{r}116 \\
76 \\
93\end{array}$ & $\begin{array}{l}96 \\
81 \\
85\end{array}$ & $\begin{array}{l}440 \\
270 \\
370\end{array}$ & $\begin{array}{l}0.09 \\
0.08 \\
0.09\end{array}$ \\
\hline 4 & 26 & $\begin{array}{l}\text { Before operation } \\
1 \mathrm{mth} \text {. after } \\
9 \mathrm{mth} \text {. after }\end{array}$ & $\begin{array}{l}\text { I } \\
\text { ? }\end{array}$ & $\stackrel{36 / 14}{=}$ & $\begin{array}{r}100 \\
72 \\
107\end{array}$ & $\begin{array}{l}80 \\
97 \\
85\end{array}$ & $\begin{array}{l}400 \\
400 \\
500\end{array}$ & $\begin{array}{l}0.11 \\
0.09 \\
0.14\end{array}$ \\
\hline 5 & 29 & $\begin{array}{l}\text { Before operation } \\
1 \mathrm{mth} \text {. after } \\
14 \mathrm{mth} \text {. after }\end{array}$ & $\frac{0}{0}$ & $\stackrel{34 / 12}{=}$ & $\begin{array}{l}119 \\
112 \\
120\end{array}$ & $\begin{array}{l}80 \\
88 \\
88\end{array}$ & $\begin{array}{l}400 \\
360 \\
410\end{array}$ & $\begin{array}{l}0.14 \\
0.20 \\
0.19\end{array}$ \\
\hline 6 & 52 & $\begin{array}{l}\text { Before operation } \\
35 \text { mth. after }\end{array}$ & $\begin{array}{l}\text { II } \\
\text { O }\end{array}$ & $\stackrel{75 / 38}{-}$ & $\begin{array}{r}74 \\
100\end{array}$ & $\begin{array}{l}71 \\
69\end{array}$ & $\begin{array}{l}300 \\
360\end{array}$ & $\begin{array}{l}0.18 \\
0.25\end{array}$ \\
\hline 7 & 33 & $\begin{array}{l}\text { Before operation } \\
6 \mathrm{mth} \text {. after }\end{array}$ & II & $70 / 30$ & $\begin{array}{l}73 \\
88\end{array}$ & $\begin{array}{l}83 \\
79\end{array}$ & $\begin{array}{l}270 \\
320\end{array}$ & $\begin{array}{l}0.14 \\
0.14\end{array}$ \\
\hline
\end{tabular}

Abbreviations as in Table I. Disability according to Nomenclature and Criteria for Diagnosis of Diseases of the Heart and Blood Vessels (1953).

flow yields a $\mathrm{P} \times \mathrm{F}$ product which is also low.

It may be concluded, therefore, that while an increase in pulmonary flow alone or in pulmonary arterial pressure alone is not associated with a low lung compliance, the combination of these usually is.

Effects of Surgery. Table II shows the findings in seven patients studied before and after successful closure of an atrial septal defect. There was no uniform change in forced vital capacity or airways resistance, but in four patients out of the seven there was a rise in compliance following surgery (Fig. 12). Pre- and post-operative measurements of FRC in Cases 4 and 7 showed that this did not change significantly (3.0 to 3.1 litres in the former, and 3.8 to 3.7 litres in the latter). Case 1 is of particular interest, in that dyspnoea improved remarkably as a result of the operation yet ventilatory capacity deteriorated, possibly as a result of taking up heavy smoking again after the operation. There was a marked rise in pulmonary compliance.

\section{Discussion}

It is of interest that in his original paper on congenital defects of the ventricular septum, Eisenmenger wrote in 1898 that "in ventricular septal defect ... the pulmonary circulation was overfilled, the systemic circulation underfilled; increased stiffness of the lungs hindered ventilation and hampered gaseous exchange...". It is perhaps surprising

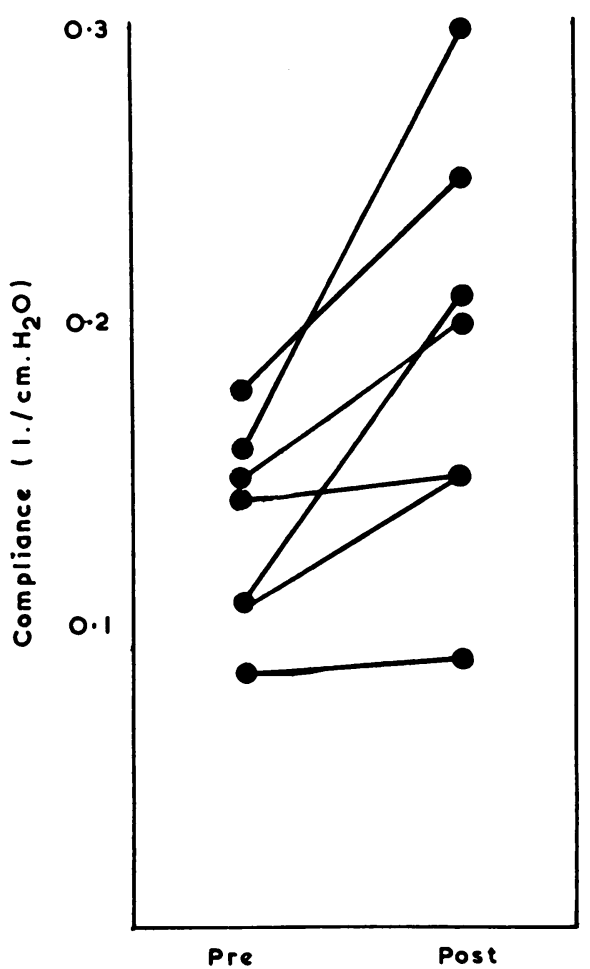

Fig. 12.-Lung compliance in four patients before, and at four or more months after closure of an atrial septal defect. 
that so few data yet exist about the function of the lungs in congenital heart disease.

McIlroy and Apthorp (1958) studied lung function in patients with pulmonary hypertension and found in general a variable reduction in lung compliance. Their cases included five with ventricular septal defect, all in the Eisenmenger category: in only one of these (Case 12) was the lung compliance reduced. Woolf (1963), in a study of 45 patients with atrial septal defect, ventricular septal defect, or both, found that a number of them had low pulmonary compliance, but case details were not given and the patients were not designated or separated in the analysis, according to their hæmodynamic status. Little difficulty in ventilation was observed in these cases. There was no statistically significant relation between mean pulmonary arterial pressure and compliance during exercise, though of 11 patients with compliance less than 0.1 litre/cm., 8 had a mean pulmonary arterial pressure greater than $30 \mathrm{~mm}$. Hg. Wessel, Kezdi, and $\mathrm{Cu}-$ gell (1964) studied 12 patients with severe pulmonary hypertension: 4 had atrial septal or ventricular septal defects, but no cardiac defects were demonstrated in the other 8 , one of whom was shown at necropsy to have "primary pulmonary hypertension" and another by lung biopsy to have schistosomiasis. The mean pulmonary arterial pressures at rest varied between 40 and $90 \mathrm{~mm}$. $\mathrm{Hg}$. Vital capacities were normal in all except the patient with schistosomiasis. The residual volume was moderately increased in all patients except one, and maximum breathing capacity was normal in 8 and only slightly reduced in 4 . With the exception of one patient, all had an abnormally large physiological dead space and a high ratio of dead space to tidal volume, which increased further with exercise. The steady-state diffusing capacity, by the end-tidal method, was normal or slightly decreased at rest. Diffusion increased normally with increasing oxygen consumption during exercise in 7 patients, though in one other it did not increase even with strenuous exertion.

In our studies we have seen a diminution of compliance in the presence of hyperkinetic pulmonary hypertension. It is clear from our results and those of the authors mentioned above that in hypertensive pulmonary vascular disease a diminution of compliance is not of necessity associated with a restriction of vital capacity. There have been a number of studies in man and in animals relating the mechanical properties of the lung to pulmonary "congestion", though the exact meaning and significance of the latter have not always been clear. Rapid intravenous infusion (Pryor and Page, 1954), the inflation of pressure suits (Lewis, Forster, and
Beckman, 1956; Bondurant, Hickam, and Isley, 1957; Obenour et al., 1963), and the immersion of a limb in ice-cold water (Bondurant et al., 1957) led to a fall in lung compliance in man. Compression of the pulmonary veins in the cat (Drinker, Peabody, and Blumgart, 1922), the injection of blood into the pulmonary artery of the dog or clamping of the pulmonary vein (Mack, Crossman, and Katz, 1947); and infusion of saline in dogs (Heyer, Holman, and Shires, 1948), likewise increased the stiffness of the lungs.

Borst et al. (1957) recorded pressure-volume curves of the lungs of dogs with the chest open at different rates of pulmonary blood flow and left atrial pressure, but found relatively small changes in lung compliance. They questioned the validity of the previous experimenters' results, concluding that the relatively large changes in the mechanical properties of the lungs in patients with congestive heart failure must be due to factors other than pulmonary congestion, such as effusion, chronic changes in vessel walls, or increased heart size. The experiments of Frank, Radford, and Whittenberger (1959) extended the range of vascular pressure used by Borst et al. (1957) in open-chested dogs and by Cook et al. (1959) in closed-chested dogs, supporting the impression that vascular congestion by itself has only a limited effect on the elastic properties of the lungs.

Nevertheless, the failure of some experimenters to produce marked changes in lung compliance in animals by altering pressure-flow relations in the pulmonary artery bears no necessary relevance to the situation in patients with hyperkinetic pulmonary hypertension, since the vasculature is abnormal in the latter circumstances. Saxton et al. (1956) found no change in pulmonary compliance after mitral valvotomy, and concluded that pulmonary vascular pressures had little effect on it. Their measurements were made within a few weeks of operation. This is too early properly to assess the effects of surgery, since the traumatic and inflammatory changes in lung and chest-wall have not resolved. Nor is it clear how they were able with confidence to observe a "striking improvement in dyspnœa" in their patients within two weeks of operation.

The increase in compliance which we observed after closure of atrial septal defects, together with the impression of surgeons and anæsthetists that there is an immediate diminution of lung rigidity on banding the pulmonary artery of infants with ventricular septal defect and hyperkinetic pulmonary hypertension (D. N. Ross, personal communication, 1965), lends support to the view that the latter affects the compliance of the lungs. We believe 
that the characteristic chest deformity of the infant with hyperkinetic pulmonary hypertension (Davies, 1959) is caused by diminished lung compliance, and the results of body plethysmograph studies in such infants are in keeping with this view (Davies, Gregg, and Singh, 1966). The highly significant correlation seen between the product of pulmonary flow and pressure (which we have designated the "hyperkinetic index") and the lung compliance provides further evidence of this. Whether or not the erectile properties of the pulmonary vasculature are responsible, by increasing the resistance of the small pulmonary vessels to distortion when they are dilated and their walls are thickened and under tension, is not established, though Wagenfoort (1960) showed that in the periphery of the lung in ventricular septal defect with hyperkinetic pulmonary hypertension a much greater area of any cross-section is occupied by vascular muscle.

It would thus be expected that in hyperkinetic pulmonary hypertension, as in mitral stenosis, the vascular contribution to the resistance to expansion of the individual alveolus might be increased. In solitary pulmonary hypertension (thromboembolic or primary), or in the Eisenmenger syndrome, the vascular lesions are "proximal" to the alveolus and the alveolar vessels are neither dilated nor under increased tension. The normal lung compliance of such patients is, therefore, not surprising.

In a study of the effects of exercise in patients with left-to-right shunts we observed that there was a rise in both pulmonary flow and pressure which, if the above reasoning is correct, would be expected to decrease further the lung compliance. In atrial septal defect with hyperkinetic pulmonary hypertension a significant correlation exists between the increment in the hyperkinetic index with exercise and the level of the resting pressure (Davies and Gazetopoulos, 1966). It is possible that this mechanism contributes to the considerable disability of such patients and to the marked clinical improvement which follows successful operation.

\section{SUMMARY}

Measurements of lung compliance and other aspects of pulmonary function have been made in 97 patients with cardiac septal defects. Hyperkinetic pulmonary hypertension is associated with a reduction in lung compliance, and a significant inverse relation exists between the product of the pulmonary blood flow index and the mean pulmonary arterial pressure (designated the hyperkinetic index) on the one hand and the lung compliance on the other. This reduction in compliance is not always associated with impaired ventilatory function. In 4 out of 7 patients lung compliance rose after surgical closure of an atrial septal defect. The significance of these findings has been discussed.

\section{REFERENCES}

Bates, D. V. (1952). The uptake of carbon monoxide in health and in emphysema. Clin. Sci., 11, 21.

Bondurant, S., Hickam, J. B., and Isley, J. K. (1957). Pulmonary and circulatory effects of acute pulmonary vascular engorgement in normal subjects. F.clin. Invest., 36, 59.

Borst, H. G., Berglund, E., Whittenberger, J. L., Mead, J., McGregor, M., and Collier, C. (1957). The effects of pulmonary vascular pressures on the mechanical properties of the lungs of anesthetized dogs. $\mathcal{F}$. clin. Invest., 36, 1708.

Cook, C. D., Mead, J., Schreiner, G. L., Frank, N. R., and Craig, J. M. (1959). Pulmonary mechanics during induced pulmonary edema in anesthetized dogs. $\mathscr{f}$. appl. Physiol., 14, 177.

Davies, H. (1959). Chest deformities in congenital heart disease. Brit. F. Dis. Chest, 53, 151.

- , and Gazetopoulos, N. (1966). Hæmodynamic changes. on exercise in patients with left-to-right shunts. Brit. Heart f., 28, 579.

—, Gregg, R. S., Jr., and Singh, V. (1966). Unpublished data, included in Thesis for D.M. (Oxon.) by Davies, H. (1966).

—, Williams, J., and Wood, P. (1962). Lung stiffness in states of abnormal pulmonary blood flow and pressure. Brit. Heart F., 24, 129.

Drinker, C. K., Peabody, F. W., and Blumgart, H. L. (1922). The effect of pulmonary congestion on the ventilation of the lungs. F. exp. Med., 35, 77.

Eisenmenger, V. (1898). Ursprung der Aorta aus beiden Ventrikeln beim Defect des Septum ventriculorum. Wien. klin. Wschr., 11, 26.

Frank, N. R., Radford, E. P., and Whittenberger, J. L. (1959). Static volume-pressure interrelations of the lungs and pulmonary blood vessels in excised cats' lungs. $\mathscr{F}$. appl. Physiol., 14, 167.

Gazetopoulos, N., and Davies, H. (1966). Ventilatory response to exercise in patients with left-to-right shunts. Brit. Heart f., 28, 590.

Helliesen, P. J., Cook, C. D., Friedlander, L., and Agathon, S. (1958). Studies of respiratory physiology in children. Pediatrics, 22, 80.

Heyer, H. E., Holman, J., and Shires, G. T. (1948). The diminished efficiency and altered dynamics of respiration in experimental pulmonary congestion. Amer. Heart f., 35, 463.

Lewis, B. M., Forster, R. E., and Beckman, E. L. (1956). The acute effects of inflation of a pneumatic suit upon pulmonary diffusing capacity in normal subjects. Clin. Res. Proc., 4, 150.

Mack, I., Crossman, M., and Katz, L. N. (1947). The effect of pulmonary vascular congestion on the distensibility of the lungs. Amer. F. Physiol., 150, 654.

Mcllroy, M. B., and Apthorp, G. H. (1958). Pulmonary function in pulmonary hypertension. Brit. Heart $\mathcal{F}$., 20, 397.

McMichael, J. (1939). A rapid method of determining lung capacity. Clin. Sci., 4, 167.

Myers, J. A. (1925). Vital Capacity of the Lungs. Williams and Wilkins, Baltimore.

Needham, C. D., Rogan, M. C., and McDonald, I. (1954). Normal standards for lung volumes, intrapulmonary gas-mixing, and maximum breathing capacity. Thorax,
9, 313 . 
Nomenclature and Criteria for Diagnosis of Diseases of the Heart and Blood Vessels (1953). 5th ed. New York Heart Association, New York.

Obenour, R. A., Saltzman, H. A., Sieker, H. O., and Green, J. L. (1963). Effects of surface-active aerosols and pulmonary congestion on lung compliance and resistance. Circulation, 28, 888.

Pryor, W. W., and Page, E. B. (1954). Changes in lung compliance associated with pulmonary vascular changes. Amer. F. Med., 16, 606.

Saxton, G. A., Jr., Rabinowitz, M., Dexter, L., and Haynes, F. (1956). The relationship of pulmonary compliance to pulmonary vascular pressures in patients with heart disease. f. clin. Invest., 35, 611.

Wagenfoort, C. A. (1960). Vasoconstriction and medial hypertrophy in pulmonary hypertension. Circulation, 22, 535.

Wessel, H. U., Kezdi, P., and Cugell, D. W. (1964). Respiratory and cardiovascular function in patients with severe pulmonary hypertension. Circulation, 29, 825.

Wood, P. (1958). The Eisenmenger syndrome or pulmonary hypertension with reversed central shunt. Brit. med. f., 2, 701 .

Woolf, C. R. (1963). Pulmonary function in adults with intracardiac septal defect. Circulation, 27, 261. 